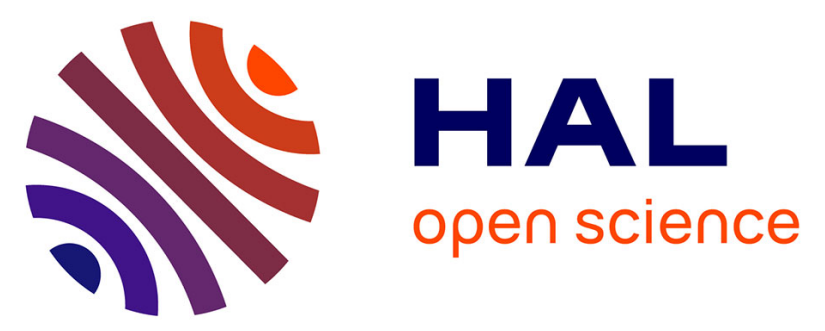

\title{
Reconfigurable metamaterial structure for 5G beam tilting antenna applications
}

Bashar Esmail, Huda Majid, Samsul Dahlan, Zuhairiah Zainal Abidin, Mohamed Himdi, Raimi Dewan, Mohamad K. A. Rahim, Adel Ashyap

\section{- To cite this version:}

Bashar Esmail, Huda Majid, Samsul Dahlan, Zuhairiah Zainal Abidin, Mohamed Himdi, et al.. Reconfigurable metamaterial structure for $5 \mathrm{G}$ beam tilting antenna applications. Waves in Random and Complex Media, 2021, 31 (6), pp.2089-2102. 10.1080/17455030.2020.1720933 . hal-02871284

\section{HAL Id: hal-02871284}

\section{https://hal-univ-rennes1.archives-ouvertes.fr/hal-02871284}

Submitted on 17 Jun 2020

HAL is a multi-disciplinary open access archive for the deposit and dissemination of scientific research documents, whether they are published or not. The documents may come from teaching and research institutions in France or abroad, or from public or private research centers.
L'archive ouverte pluridisciplinaire HAL, est destinée au dépôt et à la diffusion de documents scientifiques de niveau recherche, publiés ou non, émanant des établissements d'enseignement et de recherche français ou étrangers, des laboratoires publics ou privés. 


\section{Reconfigurable metamaterial structure for $5 \mathrm{G}$ beam tilting antenna applications}

Bashar A. F. Esmail ${ }^{a}$, Huda A. Majid ${ }^{a^{*}}$, Samsul H. Dahlan ${ }^{a}$, Zuhairiah Zainal abidin $^{\mathbf{a}}$, Mohamed Himdi ${ }^{\boldsymbol{b}}$, Raimi Dewan ${ }^{\boldsymbol{b}}$, Mohamad K. A. Rahim $^{c}$ \& Adel YI Ashyap ${ }^{a}$

${ }^{a}$ Center for Applied Electromagnetic, Universiti Tun Hussein Onn Malaysia, 86400 Parit Raja, Batu Pahat, Johor, Malaysia. (eng.bashar2@yahoo.com, mhuda@uthm.edu.my,samsulh@uthm.edu.my,zuhairia@uthm.edu.my, ashyap2007@gmail.com)

${ }^{\boldsymbol{b}}$ Institute of Electronics and Telecommunication of Rennes, University of Rennes 1, France.(mohamed.himdi@univ-rennes1.fr,raimi-bin.dewan@univ-rennes1.fr)

c School of Electrical Engineering, Faculty of Engineering, Universiti Teknolog, Malaysia 81310 UTM JB, Johor, Malaysia. (mdkamal@utm.my)

*Correspondence: Huda A. Majid

Center for Applied Electromagnetic, Universiti Tun Hussein Onn Malaysia, 86400 Parit Raja, Batu Pahat, Johor, Malaysia.

Email: mhuda@uthm.edu.my Telephone:+60 13-7025675 


\title{
Reconfigurable metamaterial structure for 5G beam tilting antenna
}

\section{applications}

\begin{abstract}
In this paper, we propose a metamaterial (MTM) structure with a reconfigurable property designed to operate at the millimetre-wave (mm-wave) spectrum. Four switches are used to achieve the reconfigurable property of the MTM with two configurations. These two configurations exhibit different refractive indices, which used to guide the radiation beam of the antenna to the desired direction. The proposed planar dipole antenna operates at the 5th generation (5G) band of $28 \mathrm{GHz}$. The electromagnetic (EM) rays of the proposed antenna pass through different MTM configurations with different phases, subsequently results in the tilting of the radiation beam toward MTM configuration of high refractive index. Simulated and measured results of the proposed antenna loaded by MTM demonstrate that the radiation beam is tilted by angles of $+34^{\circ}$ and $-31^{\circ}$ in the E-plane depending on the arrangement of two MTM configurations onto the antenna substrate. Furthermore, the gain is improved by $1.7 \mathrm{~dB}$ and $1.5 \mathrm{~dB}$ for positive and negative tilting angles, respectively. The reflection coefficients of the antenna with MTM are kept below $-10 \mathrm{~dB}$ at $28 \mathrm{GHz}$.
\end{abstract}

Keywords: Beam tilting, 5G, millimetre-wave (mm-wave), refractive index, reconfigurable metamaterial.

\section{Introduction}

Mm-wave frequencies, such as $28 \mathrm{GHz}$ and $60 \mathrm{GHz}$, are proposed to realize 5G networks with a large bandwidth, which translates directly to higher data transfer rates and low latency in signal traffic. These frequencies enable mitigation of interference as well as increase the frequency reuse factor [1, 2]. However, these frequencies suffer from high propagation loss, limiting the communications to short-range distances. To overcome this issue, a high gain directional antenna should be used at both terminals of the communication system [3]. Reconfiguring the radiation pattern of the antennas is key to enhancing the performance of the communication systems in terms of interference reduction, economizing power, and system security [4]. Various techniques have been proposed in the literature for performing the beam tilting, such as mechanical and electronic methods. In spite of the drawbacks of bulky structure and low switching speed of the mechanical method, it provides a large scan angle in comparison with other methods [5]. On the other hand, the electronic method provides high switching speed and small physical structure. However, it suffers from high losses due to the active devices used $[6,7]$.

Recently, the artificial periodic structures such as MTM [8], artificial magnetic conductor (AMC) [9], electromagnetic bandgap (EBG) [10], and frequency selective surface (FSS) [11] had been proposed for performing the beam tilting antenna. MTMs 
are artificially engineered materials with electromagnetic characteristics not found in nature. These human-made materials are commonly used in antenna design to enhance the gain, bandwidth, and efficiency and recently to tilt the radiation beam [12-14]. In [15], SRR and H-shape were combined in a one-unit cell and used as an array to tilt the radiation beam of a horn antenna by an angle of $+10^{\circ}$. This structure had a large physical size and the gain decreases when a small deflection angle is achieved. Wellknown MTM structures; split-ring resonator (SRR) and meander line were used to tilt the radiation beam of the patch antenna array at an angle of $+15^{\circ}$ albeit with a gain decrease of $1.5 \mathrm{~dB}$ at $7.3 \mathrm{GHz}$ [16]. Also, the eleven layers of MTM that arranged vertically on the patch antenna array complicate the construction and increase the cost of the antenna. Periodic J-shape unit cells were included into a leaky-wave antenna to deflect the radiation beam in both directions at angles of $\pm 15^{\circ}[17]$. In [18], $3 \times 4$ array of $\mathrm{H}$-shaped MTM is embedded into a bow-tie antenna substrate to perform a beam tilting angle at $7.5 \mathrm{GHz}$. Here, to achieve the beam tilting, it is necessary to offset the MTM unit cells form the centre of the antenna. In this case, the size of the antenna substrate is increased towards the extension of MTM array, thereby increasing the overall size of the antenna. In this work, the deflected angle is limited to one direction only, positive direction, with a small scanning angle of $17^{\circ}$. The beam tilting antenna had been implemented in both directions in [19]. The folded-line left-handed (FL-LHM) unit cells were arranged above the patch antenna to perform beam deflection at angles of $\pm 20^{\circ}$. Moreover, the gain was improved by $2.5 \mathrm{~dB}$. Although this work presents beam deflection and gain enhancement in both directions, the scanning angles need to be improved and also the structure is bulky due to the 3D arrangement of the patch antenna with MTM array. 6×7 adjacent square-shaped resonator (ASSR) unit cells were used to deflect the radiation beam of the printed dipole in both positive and negative directions [8]. The radiation beam is tilted by $25^{\circ}$ and $-24^{\circ}$ with gain enhancement in both directions. The high deflection angle of $+30^{\circ}$ is obtained by integrating a high refractive index metamaterial (HRIM) with a dipole antenna, but the tilting angle is also limited to one direction. Also, four vertical layers of MTM unit cells increase the complexity of the antenna [20]. In [21], a bow-tie antenna loaded by 5×4 double G-shaped resonator (DGS) array was proposed to perform the beam deflection in both directions. The MTM antenna achieves deflection angles of $\pm 32^{\circ}$ at $3.5 \mathrm{GHz}$. However, the multilayer of DGS that arranged vertically on the antenna substrate increase the complexity and the cost.

In this paper, a reconfigurable refractive index MTM structure is loaded to a planar antenna for radiation beam deflection at 5G candidate band of $28 \mathrm{GHz}$. The proposed structure uses a smaller number of MTM unit cells, $2 \times 3$ unit cells, to achieve positive and negative beam tilting angles with gain enhancement.

\section{The proposed MTM Structure}

The geometric layout of the proposed MTM unit cell is depicted in Figure 1(a), which consists of a square resonator with two cross-diagonal bars. The dielectric layer is Rogers RT5880 with a thickness of $0.254 \mathrm{~mm}$, a relative permittivity of 2.2, and a 
tangent loss of 0.0009 . The metallic layer is a lossy copper with a thickness of 0.035 $\mathrm{mm}$. The dimensions of the proposed unit cells are $\mathrm{L}=3.3 \mathrm{~mm}, \mathrm{~L} 1=3 \mathrm{~mm}, \mathrm{~T}=1.64 \mathrm{~mm}$, $\mathrm{F}=0.4 \mathrm{~mm}, \mathrm{G}=0.35 \mathrm{~mm}$ and $\mathrm{W}=0.2 \mathrm{~mm}$. To achieve the reconfigurable MTM structure, four switches (S1, S2, S3, and S4) are formed in the gaps of the structure, as shown in Figure 1(b). The copper strip with a size of $0.35 \times 0.2 \mathrm{~mm}$ is used to mimic the dimensions of the real PIN switches. The ON state is represented by the copper strip, whereas the vacuum represents the OFF state. Only two states of the switches (all ON and all OFF) have been studied to meet the study requirements of creating two MTM configurations (ON configuration and OFF configuration) with different refractive index values. The proper boundary conditions are applied to perform the simulation, in which the $\mathrm{x}$ - and z-axes are allocated with magnetic and electric fields, respectively, and two waveguide ports are assigned in the y-direction.

The reflection, $S_{11}$ and transmission, $S_{21}$ coefficients of the reconfigurable MTM structure are shown in Figure 2. For OFF configuration, the transmission band shows a very low loss of about $-0.16 \mathrm{~dB}$ at $28.3 \mathrm{GHz}$ because of the proper geometric arrangement of the structure. On the other hand, a robust retrieval algorithm is used to reconstruct the index of refraction of the proposed structure [22]. The real refractive index of the proposed structure for both ON and OFF configurations are displayed in Figure 3. It is noticeable that the negative refractive index differs at $28 \mathrm{GHz}$, with the ON and OFF configurations achieving 2.9 and 1.9, respectively. The main purpose of using the switches is to create different refractive indices at $28 \mathrm{GHz}$, which are used to tilt the main beam of the proposed antenna.

\section{Dipole Antenna Design}

The schematic view and the fabricated prototype of the planar dipole antenna are shown in Figure 4(a) and (b), respectively. The dipole structure and the balun are printed on the back layer and front layer of the substrate, respectively. The integrated balun is used to feed the dipole antenna, which used to transform the balanced dipoles to the unbalance coaxial connector. The integrated balun consists of a microstrip line with the open stub as shown in Figure 4 (a). The off-centered microstrip line with open stub is used to feed the dipole through a slot between the two dipole arms. The substrate layer is Rogers RT5880 with a thickness of $0.254 \mathrm{~mm}$, a dielectric constant of 2.2, and a tangent loss of 0.0009. The geometric specifications of the proposed antenna are given in the Table. 1. The length of each arm is a quarter-wavelength which can be calculated as follows:

$$
L_{a}=0.25 \lambda \text { and } \lambda=\frac{c}{f \sqrt{\varepsilon_{e}}}
$$

Where $L_{a}$ is dipole arm length, $\lambda$ is the wavelength, $\mathrm{C}$ is the speed of light in free space and $f$ is the operating frequency. The effective dielectric constant $\left(\varepsilon_{e}\right)$ is equal to the average of the dielectric constant of the substrate $\left(\varepsilon_{r}\right)$ and air which can be expressed as in [23] 


$$
\varepsilon_{e}=\frac{\left(1+\varepsilon_{r}\right)}{2}
$$

Thus,

$$
L_{a}=0.25 \frac{c}{f \sqrt{\left(1+\varepsilon_{r}\right) / 2}}
$$

At the operation frequency of the proposed antenna, $28 \mathrm{GHz}$, the $L_{a}$ is roughly $2.1 \mathrm{~mm}$ for Rogers RT5880 substrate which equals the simulated length using CST software.

The simulated and measured reflection coefficients of the dipole antenna are plotted in Figure 5(a). The simulation result shows that the antenna operates at $28 \mathrm{GHz}$ with a reflection coefficient, $S_{11}$ of $-24.2 \mathrm{~dB}$ and wide bandwidth. The proposed antenna was fabricated and measured to validate the simulated results. The southwest end-launch connector of $1.85 \mathrm{~mm}$ had been used in the measurements to verify the antenna characteristics. There is a good match between the simulated and measured results. However, a small downshift in the measured results was observed due to the fabrication tolerance and the sensitivity of measurement at the high-frequency range. Figures 5(b) and (c) present the simulated and measured radiation patterns of the proposed antenna in the E-plane and H-plane at $28 \mathrm{GHz}$, respectively. It is obvious that the E-plane radiation pattern of the dipole is directional, with a peak gain of $5.12 \mathrm{~dB}$ at $28 \mathrm{GHz}$. The radiation patterns in E-plane and H-plane radiates to the end-fire direction (y) with no tilting. The simulation and measurement results show good agreement.

\section{Performance and analysis of antenna with MTM unit cells}

\subsection{Theoretical concept of beam tilting}

The theoretical concept of radiation beam tilting relies on two MTM configurations of different refractive index which placed in the way of the EM rays. According to Snell's law, when the EM wave travels into two mediums of different refractive indices, it refracted in a predefined angle. The various refractive index values of the reconfigurable MTM create phase change for the EM wave, which leads to beam tilting. This concept is used here to tilt the radiation beam of the dipole antenna in E-plane. The best way to obtain mediums with different refractive index values on the restricted area of the substrate is by using suitable MTM design with reconfigurability property. The two configurations of MTM are positioned in the proximity of the EM source (dipole antenna) as shown in Figure 6 . The $2 \times 3$ unit cells of reconfigurable MTM are inserted into a dipole antenna substrate with the overall dimensions of $9.9 \mathrm{~mm} \times 6.6 \mathrm{~mm}$. The rays of an EM wave travel over the reconfigurable MTM structure with different lengths and directions. As described in [24], the calculation of the array factor (AF) at far-field is used to determine the resultant effect of each ray. The position of each element is depicted in Figure 6.

The AF can be expressed as 


$$
\mathrm{AF}=1+e^{i k d_{1} \cos \gamma_{1}}+e^{i k d_{2} \cos \gamma_{2}}
$$

Where $k$ and $d$ are the wavenumber and the length of each ray, respectively. The unit vectors $\hat{a}_{m 10}$ and $\hat{a}_{m 20}$ that extends from the feed point $o$ to the two MTM configurations are given by

$$
\begin{gathered}
\hat{a}_{m 1 o}=0.6 \hat{a}_{x}+0.8 \hat{a}_{y} \\
\hat{a}_{m 2 o}=-0.33 \hat{a}_{x}+0.94 \hat{a}_{y}
\end{gathered}
$$

where $\alpha_{1}=53.4^{\circ}$ and $\alpha_{2}=70.7^{\circ}$

$$
\hat{a}_{r o}=\sin \theta \cos \varphi \hat{a}_{x}+\sin \theta \sin \varphi \hat{a}_{y}+\cos \theta \hat{a}_{z}
$$

The angles $\gamma_{1}$ and $\gamma_{2}$ are obtained by the dot product of $\hat{a}_{r o}$ with $\hat{a}_{m 1 o}$ and $\hat{a}_{m 20}$, respectively.

$$
\begin{aligned}
& \cos \gamma_{1}=\hat{a}_{m 10} \cdot \hat{a}_{r o}=0.6 \sin \theta \cos \varphi+0.8 \sin \theta \sin \varphi \\
& \cos \gamma_{2}=\hat{a}_{m 2 o} . \hat{a}_{r o}=-0.33 \sin \theta \cos \varphi+0.94 \sin \theta \sin \varphi
\end{aligned}
$$

At $\theta=90^{\circ}$ plane, equations (8) and (9) are reduced to

$$
\begin{aligned}
& \cos \gamma_{1}=0.6 \cos \varphi+0.8 \sin \varphi \\
& \cos \gamma_{2}=-0.33 \cos \varphi+0.94 \sin \varphi
\end{aligned}
$$

Thus,

$$
\mathrm{AF}=1+e^{i k d_{1}(0.6 \cos \varphi+0.8 \sin \varphi)}+e^{i k d_{2}(-0.33 \cos \varphi+0.94 \sin \varphi)}
$$

In order to calculate the radiation pattern of the dipole antenna loaded by reconfigurable MTM structure, the AF is multiplied by the dipole antenna element factor which is given by $\cos ((\pi / 2) \cos \varphi) / \sin \varphi$ [25]. The dipole antenna's main beam is tilted at an angle of $28^{\circ}$ when the reconfigurable MTM unit cells are loaded as depicted in Figure 7.

\subsection{Antenna beam tilting}

To achieve positive and negative tilting angles, $2 \times 3$ MTM unit cells with different configurations are inserted into the antenna substrate, as shown in Figures 8 and 9, respectively. To obtain a positive tilting angle, $2 \times 2$ unit cells with the $\mathrm{ON}$ configuration extended from the centre to the right side of the substrate, while $2 \times 1$ unit cells with the OFF configuration were placed to the left side of the substrate. Figures 8 (a) and (b) display the designed configuration and its fabrication prototype, respectively. This 
arrangement leads to the creation of two MTM configurations with different refractive indices in the proximity of the antenna radiating elements, thereby tilting the radiation beam toward the MTM of high refractive index (ON configuration). The simulated and measured results of the reflection coefficients are plotted in Figure 10. The reflection coefficient, $S_{11}$ has been kept lower than $-10 \mathrm{~dB}$ at $28 \mathrm{GHz}$. The discrepancy between the simulated and measured results is due to the fabrication tolerance.

Figures 11 (a), (b), (c) and (d) show the normalized simulated and measured results of the radiation patterns in the E-plane at $27.7 \mathrm{GHz}, 28 \mathrm{GHz}$, and $28.3 \mathrm{GHz}$ and in $\mathrm{H}$-plane at $28 \mathrm{GHz}$, respectively. The radiation beam is tilted by an angle of $+34^{\circ}$ in the E-plane at $28 \mathrm{GHz}$. The measured result confirms that the main beam is deflected by $+34^{\circ}$. To carry out a negative tilting angle, the arrangement of the MTM configurations is reversed compared to that of the positive deflection angle. Figure 9 (a) and (b) depicts the designed and prototype of antenna incorporated with $2 \times 3$ MTM unit cells for negative tilting in E-plane. $2 \times 2$ unit cells with the ON configuration spread from the centre to the left side of the substrate and $2 \times 1$ unit cells with the OFF configuration were placed to the right side of the antenna. From Figure 10, there is good matching between the measured and simulated reflection coefficients. The radiation beam is tilted toward the high refractive index configuration at an angle of $-31^{\circ}$ in the E-plane at 28 $\mathrm{GHz}$, as shown in Figure 11. The including of MTM array affects the shape of the radiation pattern in H-plane, however, the MTM antenna still radiates with no tilting for both directions as shown in Figure 11 (d). Overall, the measured radiation patterns are consistent well with the simulation results for both positive and negative tilting angles. The 3-degrees difference between the positive and negative tilting angles is due to the integrated balun that used to feed the proposed antenna. The design of integrated balun helps MTM array to guide the main beam of the antenna toward a more positive direction.

Figure 12 displays the simulated and measured gains for the dipole antenna, antenna with MTM for positive tilting and antenna with MTM for negative tilting. The gain is enhanced by $1.7 \mathrm{~dB}$ when the beam is tilted towards a positive direction $(+\mathrm{y})$, which means about $24.8 \%$ of gain enhancement over the dipole antenna. On the other hand, the gain improves by $1.5 \mathrm{~dB}(22.4 \%)$ when the beam is tilted in a negative direction $(-y)$. This enhancement in the gain can help to mitigate the propagation loss resulting from increasing the operating frequency of the antenna. The measured gains agree well with the simulated ones for the dipole antenna and MTM antenna. Table 2 presents the comparison of the recent literature with this work in terms of antenna, frequency of operation, radiation pattern tilting angle, gain enhancement, and the used MTM structure. The proposed antenna with MTM array produces high deflection angles with an acceptable increase in the gain in both directions compared to other reported literature.

\section{Conclusion}

A reconfigurable metamaterial (MTM) structure is proposed to operate at the mm-wave frequency range. Four switches have been used to achieve two MTM configurations with different refractive indices, which are used to tilt the radiation beam of the proposed 5G antenna at $28 \mathrm{GHz}$. The performance of the two MTM configurations had 
been studied, and their refractive indices had been reconstructed. Simulated and measured results show that MTM with two configurations can tilt the radiation beam of the proposed antenna in both directions at angles of $+34^{\circ}$ and $-31^{\circ}$ in the E-plane. The 3degrees difference between the positive and negative tilting angles is due to the integrated balun that used to feed the proposed antenna. Moreover, the beam tilting exhibits gain enhancements of $24.8 \%$ and $22.4 \%$ for positive and negative tilting angles, respectively, due to the inclusion of MTM in the path of the EM rays. The proposed structure is a promising candidate for beamforming applications at the $5 \mathrm{G}$ candidate band of $28 \mathrm{GHz}$.

\section{Funding}

This work was supported by Ministry of Higher Education (MOHE), Research Center of Applied Electromagnetics, Research Management Centre, Universiti Tun Hussein Onn Malaysia (UTHM) under Grant (Vote No: CRG K034).

\section{References}

[1]Ghosh S, Sen D. An Inclusive Survey on Array Antenna Design for Millimeter-Wave Communications. IEEE Access. 2019; 7:83137-61.

[2]Sulyman AI, Nassar AT, Samimi MK, et al. Radio propagation path loss models for 5G cellular networks in the $28 \mathrm{GHz}$ and $38 \mathrm{GHz}$ millimeter-wave bands. IEEE Commun. Mag. 2014;52(9):78-86.

[3]Jiang H, Si LM, Hu W, et al. A Symmetrical Dual-Beam Bowtie Antenna with Gain Enhancement Using Metamaterial for 5G MIMO Applications. IEEE Photon. J. 2019 ;11(1):1-9.

[4]Tang MC, Zhou B, Ziolkowski RW. Low-profile, electrically small, Huygens source antenna with pattern-reconfigurability that covers the entire azimuthal plane. IEEE Trans. Antennas Propag. 2017;65(3):1063-1072.

[5]Sanchez-Olivares P, Masa-Campos JL, Muriel-Barrado AT, et al. Mechanically Reconfigurable Linear Array Antenna Fed by a Tunable Corporate Waveguide Network with Tuning Screws. IEEE Antennas Wireless Propag. Lett. 2018;17(8):1430-1434.

[6]Chen SL, Qin PY, Lin W, et al. Pattern-reconfigurable antenna with five switchable beams in elevation plane. IEEE Antennas Wireless Propag. Lett. 2018;17(3):454-457.

[7]Ojaroudi Parchin N, Jahanbakhsh Basherlou H, Al-Yasir YI, et al. Recent developments of reconfigurable antennas for current and future wireless communication systems. Electronics. 2019;8(2):128.

[8]Esmail BA, Majid HB, Dahlan SH, et al. Planar antenna beam deflection using low-loss metamaterial for future 5G applications. Int J RF Microw Comput Aided Eng. 2019:e21867.

[9]Kyriazidou C A, Contopanagos H, Yoon S, et al. 3D package-integrated artificial magnetic conductor antenna arrays for $60 \mathrm{GHz}$ transceivers. J Electromagn Waves Appl. 2016; 30(18):2365-2389.

[10]Abdulhameed MK, Zakaria Z, Ibrahim IM, et al. Radiation Control of Microstrip Patch Antenna by Using Electromagnetic Band Gap. AEU - Int J Electron Commun. 2019:152835.

[11]Kakhki MB, Mantash M, Kesavan A, et al. Millimeter-Wave Beam-Tilting Vivaldi Antenna with Gain Enhancement Using Multilayer FSS. IEEE Antennas Wireless Propag. Lett., 2018 Oct 1;17(12):2279-83.

[12]Patel SK, Shah KH, Kosta YP. Frequency-reconfigurable and high-gain metamaterial microstrip-radiating structure. Waves Random Complex Media. 2019;29(3):523-39.

[13]Aeini M, Jarchi S, Faraji-Dana R. Compact, wideband-printed quasi-Yagi antenna using spiral metamaterial resonators. Electron. Lett. 2017;53(21):1393-1394.

[14]Binion JD, Lier E, Hand TH, et al. A metamaterial-enabled design enhancing decades-old short backfire antenna technology for space applications. Nat. Commun. 2019;10(1):108. 
[15]Liu Y, Liu C, Jin X, et al. Beam steering by using a gradient refractive index metamaterial planar lens and a gradient phase metasurface planar lens. Microw Opt Technol Lett. 2018;60(2):330-337.

[16]Barati H, Fakheri MH, Abdolali A. Experimental demonstration of metamaterial-assisted antenna beam deflection through folded transformation optics. J. Opt. 2018 Jul 2;20(8):085101.

[17]Luo Y, Kikuta K, Han Z, et al. An active metamaterial antenna with MEMS-modulated scanning radiation beams. IEEE Electron Device Lett. 2016;37(7):920-923.

[18]Dadgarpour A, Zarghooni B, Virdee BS, et al. Beam tilting antenna using integrated metamaterial loading. IEEE Trans. Antennas Propag. 2014;62(5):2874-2879.

[19]Le MT, Nguyen QC, Vuong TP. Design of high-gain and beam steering antennas using a new planar folded-line metamaterial structure. Int. J. Antennas Propag. 2014; 2014:1-16.

[20]Dadgarpour A, Zarghooni B, Virdee BS, et al. Improvement of gain and elevation tilt angle using metamaterial loading for millimeter-wave applications. IEEE Antennas Wireless Propag. Lett. 2015; 15:418-420.

[21]Dadgarpour A, Zarghooni B, Virdee BS, et al. Enhancement of tilted beam in elevation plane for planar end-fire antennas using artificial dielectric medium. IEEE Trans. Antennas Propag. 2015;63(10):4540-4545.

[22]Chen X, Grzegorczyk TM, Wu BI, et al. Robust method to retrieve the constitutive effective parameters of metamaterials. Phys. Rev. E. 2004;70(1):016608.

[23]Lin CC, Kuo LC, Chuang HR. A horizontally polarized omnidirectional printed antenna for WLAN applications. IEEE Trans. Antennas Propag. 2006;54(11):3551-3556.

[24]Islam MR, Ali M. A $900 \mathrm{MHz}$ beam steering parasitic antenna array for wearable wireless applications. IEEE Trans. Antennas Propag. 2013;61(9):4520-4527.

[25]Islam MR, Ali M. Elevation plane beam scanning of a novel parasitic array radiator antenna for $1900 \mathrm{MHz}$ mobile handheld terminals. IEEE Trans. Antennas Propag. 2010;58(10):3344-3352. 


\section{$\underline{\text { Tables }}$}

Table 1. Geometric specifications of the proposed antenna

\begin{tabular}{cccc}
\hline Parameter & Value $(\mathrm{mm})$ & Parameter & Value $(\mathrm{mm})$ \\
\hline $\mathrm{X}$ & 12 & $\mathrm{~L} 1$ & 2.1 \\
$\mathrm{Y}$ & 16 & $\mathrm{~W} 2$ & 0.7 \\
$\mathrm{~L}$ & 6 & $\mathrm{~W} 3$ & 0.5 \\
$\mathrm{~W}$ & 10 & $\mathrm{~W} 4$ & 1.55 \\
$\mathrm{~W} 1$ & 4 & $\mathrm{Ws}$ & 0.7 \\
$\mathrm{La}$ & 2.1 & $\mathrm{Wd}$ & 0.8 \\
$\mathrm{~L} 2$ & 0.5 & $\mathrm{~s}$ & 0.5 \\
\hline
\end{tabular}

Table 2. Comparison of the present work with that reported literature for beam deflection using MTM structures

\begin{tabular}{|c|c|c|c|c|c|c|}
\hline Ref. & $\begin{array}{c}\text { Antenna } \\
\text { type }\end{array}$ & $\begin{array}{l}\text { (Frequency } \\
\text { band) }\end{array}$ & $\begin{array}{l}\text { Titling } \\
\text { angles }\end{array}$ & Gain & Complexity & $\begin{array}{l}\text { MTM } \\
\text { shape }\end{array}$ \\
\hline [15] & $\begin{array}{c}\text { Horn } \\
\text { antenna }\end{array}$ & $\begin{array}{l}\text { Ku- band } \\
\text { (15 GHz) }\end{array}$ & $\begin{array}{c}+10^{\circ} \\
\text { Posit. tilt }\end{array}$ & $\begin{array}{c}\text { Reduced by } \\
0.48 \mathrm{~dB}\end{array}$ & $\begin{array}{c}\text { High } \\
\text { (3D structure) }\end{array}$ & $\begin{array}{l}\text { SRR and } \\
\text { H-shape }\end{array}$ \\
\hline [16] & $\begin{array}{l}\text { Patch } \\
\text { antenna }\end{array}$ & $\begin{array}{l}\text { C-band } \\
(7.3 \mathrm{GHz})\end{array}$ & $\begin{array}{c}\quad+15^{\circ} \\
\text { Posit. tilt }\end{array}$ & $\begin{array}{c}\text { Reduced by } \\
1.5 \mathrm{~dB}\end{array}$ & $\begin{array}{c}\text { High } \\
\text { (3D tringle } \\
\text { structure) }\end{array}$ & $\begin{array}{l}\text { SRR and } \\
\text { meander } \\
\text { line }\end{array}$ \\
\hline [17] & $\begin{array}{c}\text { leaky-wave } \\
\text { antenna }\end{array}$ & $\begin{array}{l}\text { X-band } \\
(8 \mathrm{GHz})\end{array}$ & $\begin{array}{c} \pm 15^{\circ} \\
\text { Posit. and } \\
\text { negat. tilt }\end{array}$ & - & $\begin{array}{l}\text { High (using } \\
\text { active } \\
\text { component) }\end{array}$ & J-shape \\
\hline [18] & $\begin{array}{l}\text { Bow-tie } \\
\text { antenna }\end{array}$ & $\begin{array}{l}\text { C-band } \\
(7.5 \mathrm{GHz})\end{array}$ & $\begin{array}{c}+17^{\circ} \\
\text { Posit. tilt }\end{array}$ & $\begin{array}{c}\text { Enhanced } \\
\text { by } 2.73 \mathrm{~dB}\end{array}$ & low & H-shape \\
\hline [19] & $\begin{array}{l}\text { patch } \\
\text { antenna }\end{array}$ & $\begin{array}{l}\text { C-band } \\
(5.8 \mathrm{GHz})\end{array}$ & $\begin{array}{l} \pm 20^{\circ} \text { Posit. } \\
\text { and negat. } \\
\text { tilt }\end{array}$ & $\begin{array}{l}\text { Enhanced } \\
\text { by } 2.5 \mathrm{~dB}\end{array}$ & $\begin{array}{c}\text { High } \\
\text { (3D structure) }\end{array}$ & FL-LHM \\
\hline [8] & $\begin{array}{c}\text { Dipole } \\
\text { antenna }\end{array}$ & $\begin{array}{c}\text { S-band } \\
3.5 \mathrm{GHz}\end{array}$ & $\begin{array}{c}+25^{\circ} \text { posit } \\
\text { tilt and }-24^{\circ} \\
\text { negat. tilt }\end{array}$ & $\begin{array}{c}\text { Enhanced } \\
\text { by } 3 \mathrm{~dB} \\
\text { posit tilt } \\
\text { and } 2.7 \mathrm{~dB} \\
\text { negat. tilt }\end{array}$ & low & ASSR \\
\hline [20] & $\begin{array}{l}\text { Dipole } \\
\text { antenna }\end{array}$ & $\begin{array}{l}\text { V-band } \\
\text { (60 GHz) }\end{array}$ & $\begin{array}{l}+30^{\circ} \text { posit. } \\
\text { tilt }\end{array}$ & $\begin{array}{l}\text { Enhanced } \\
\text { by } 2.7 \mathrm{~dB}\end{array}$ & $\begin{array}{c}\text { High } \\
\text { (3D structure) }\end{array}$ & HRIM \\
\hline $\begin{array}{l}\text { This } \\
\text { work }\end{array}$ & $\begin{array}{c}\text { Dipole } \\
\text { antenna }\end{array}$ & $\begin{array}{l}\text { Ka-band } \\
\text { (28 GHz) }\end{array}$ & $\begin{array}{c}+34^{\circ} \text { posit } \\
\text { tilt and }-31^{\circ} \\
\text { negat. tilt }\end{array}$ & $\begin{array}{c}\text { Enhanced } \\
\text { by } 1.72 \mathrm{~dB} \\
\text { posit. tilt } \\
\text { and } 1.5 \mathrm{~dB} \\
\text { negat. tilt }\end{array}$ & $\begin{array}{l}\text { Low profile } \\
\text { structure }\end{array}$ & $\begin{array}{c}\text { Square } \\
\text { resonator } \\
\text { with two } \\
\text { cross- } \\
\text { diagonal }\end{array}$ \\
\hline
\end{tabular}




\section{Figures}

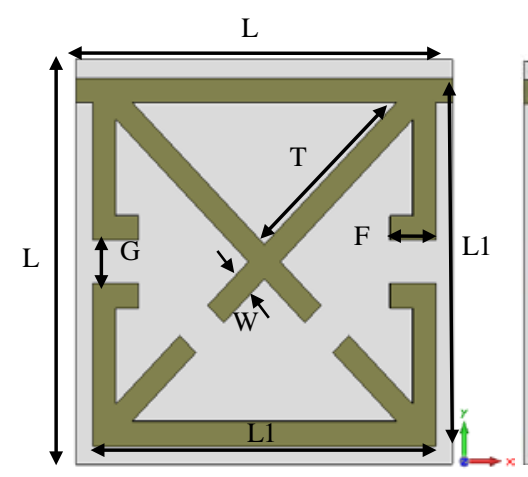

(a)

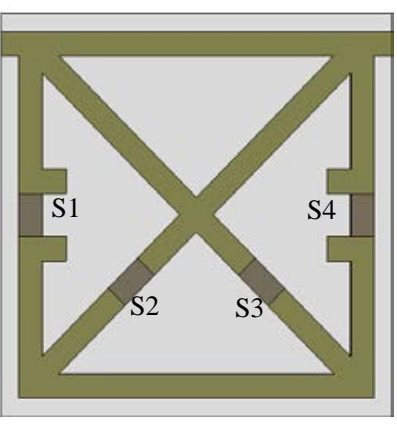

(b)

Figure 1. (a) Geometric layout of the proposed MTM unit cell (b) reconfigurable unit cell using four switches.

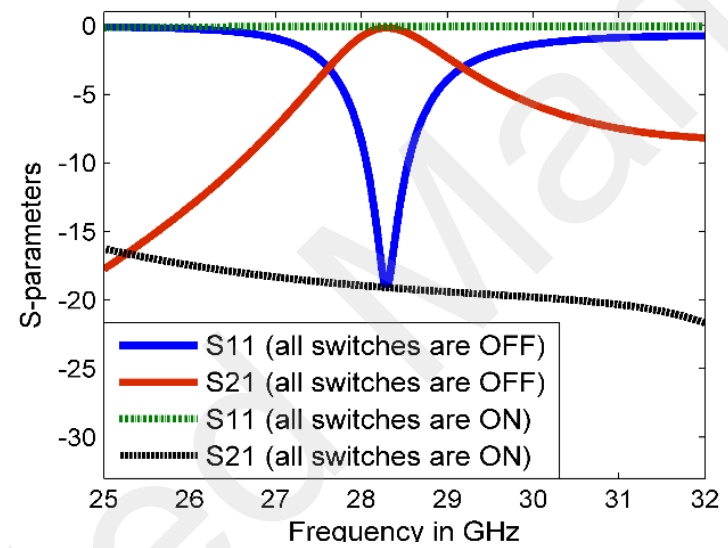

Figure 2. Reflection and transmission coefficients of the reconfigurable MTM structure. 


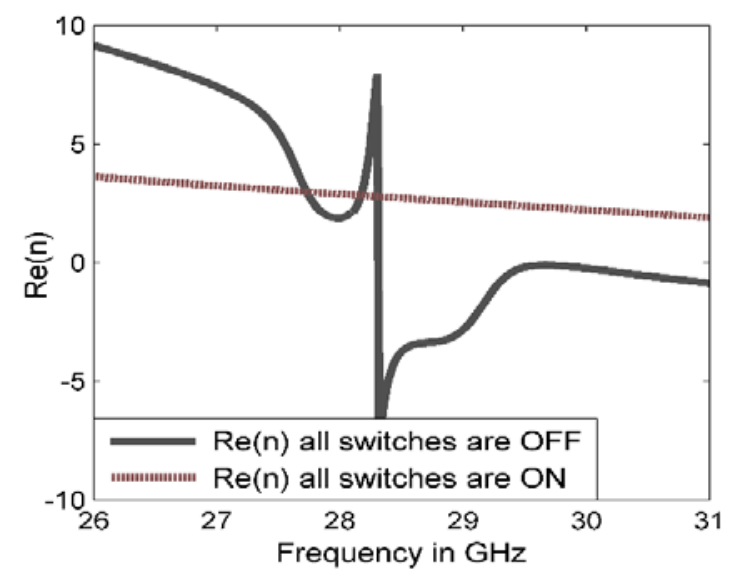

Figure 3. Real refractive index of the reconfigurable MTM structure.

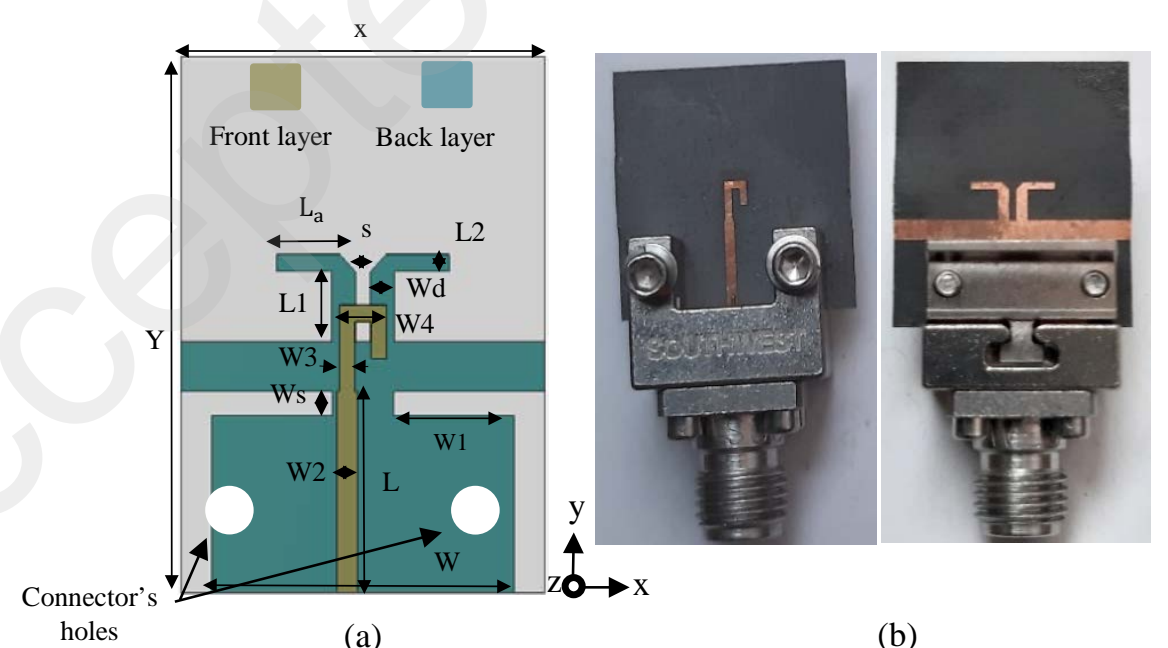

Figure 4. (a) Schematic view of the planar dipole antenna (b) front and back layers of the fabricated prototype. 


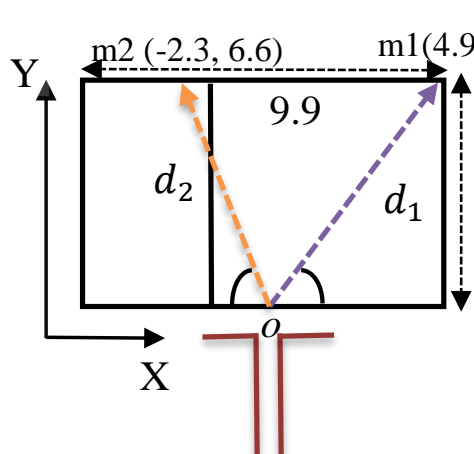

(a)

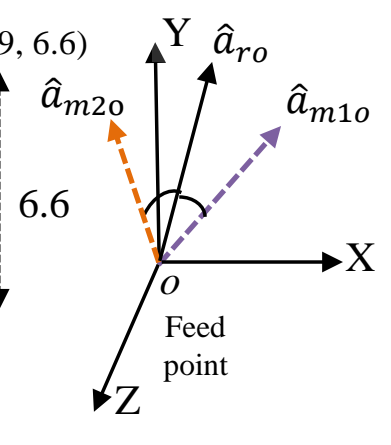

(b)

Figure 6. (a) Two MTM configurations on xy-plane (b) EM ray routes and their locations from the feed point in the coordinate plane for array factor and radiation pattern calculations.

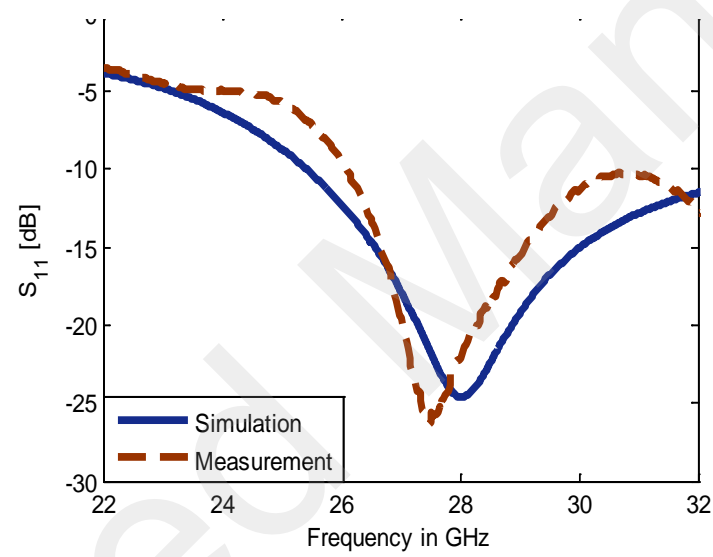

(a)

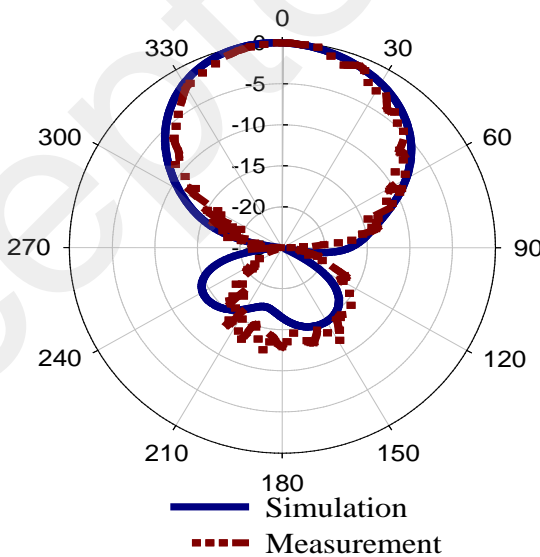

(b)

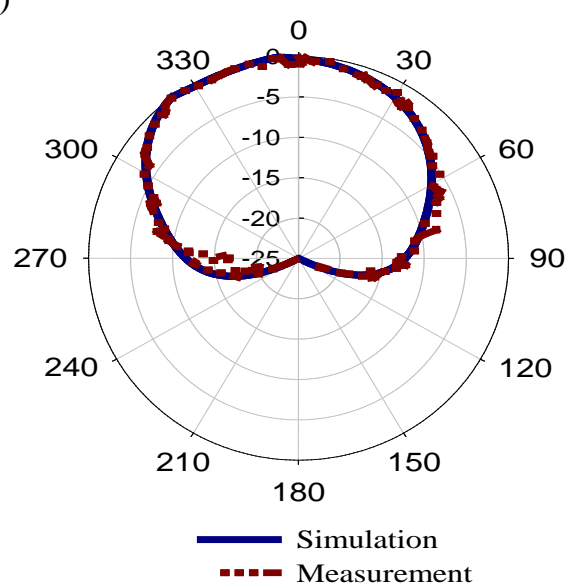

(c)

Figure 5. Simulated and measured results (a) Reflection coefficient, (b) radiation pattern in E-plane, and (c) radiation pattern in $\mathrm{H}$-plane at $28 \mathrm{GHz}$. 


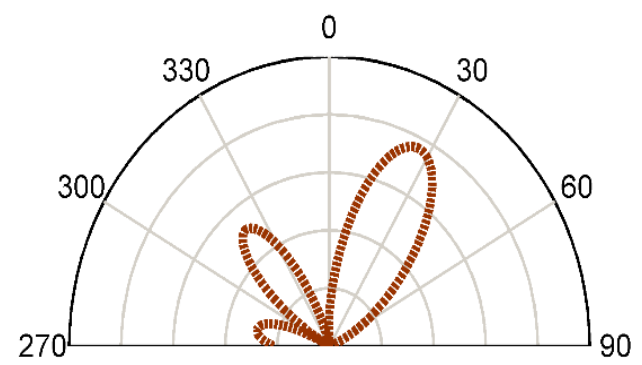

Figure 7. Radiation pattern of the proposed antenna loaded by reconfigurable MTM.

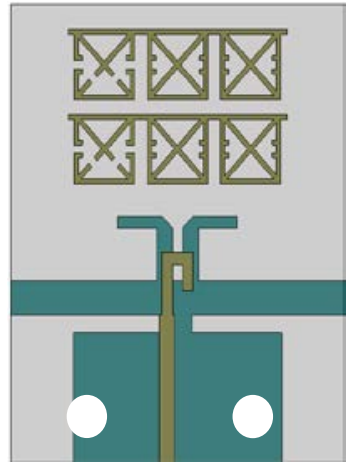

(a)

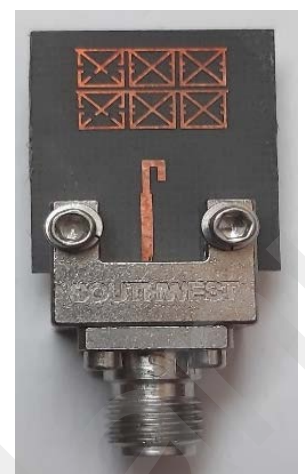

(b)

Figure 8. Antenna loaded MTM for positive tilting a) schematic view of MTM antenna (b) photographs of the fabricated antenna. 


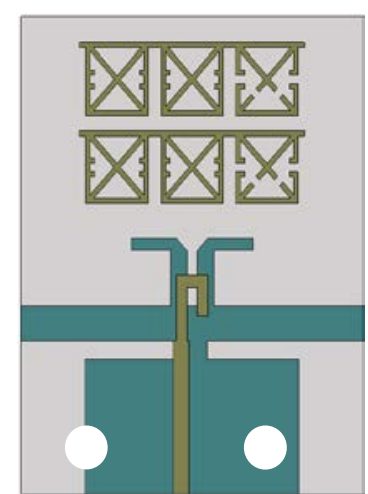

(a)

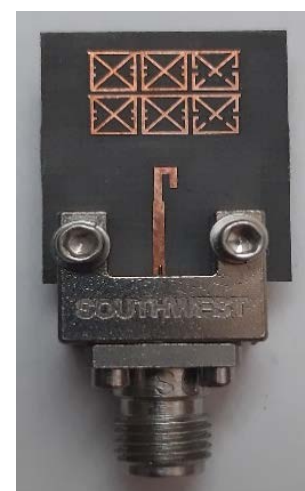

(b)

Figure 9. Antenna loaded MTM for negative tilting a) schematic view of MTM antenna (b) photographs of the fabricated antenna.

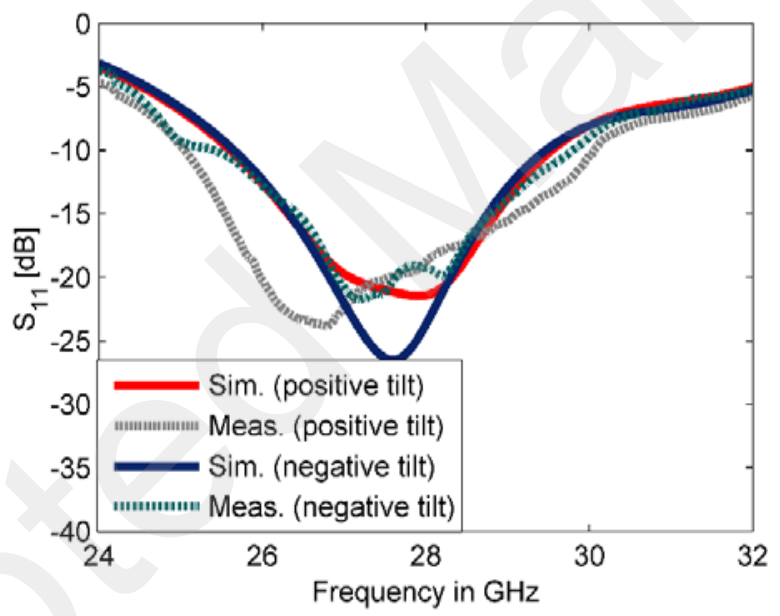

Figure 10. Simulated and measured reflection coefficient results of the proposed antenna with MTM (positive and negative tilts). 

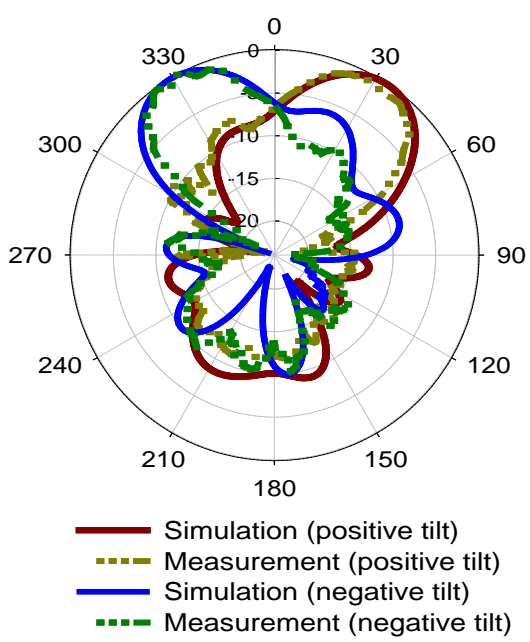

(a)

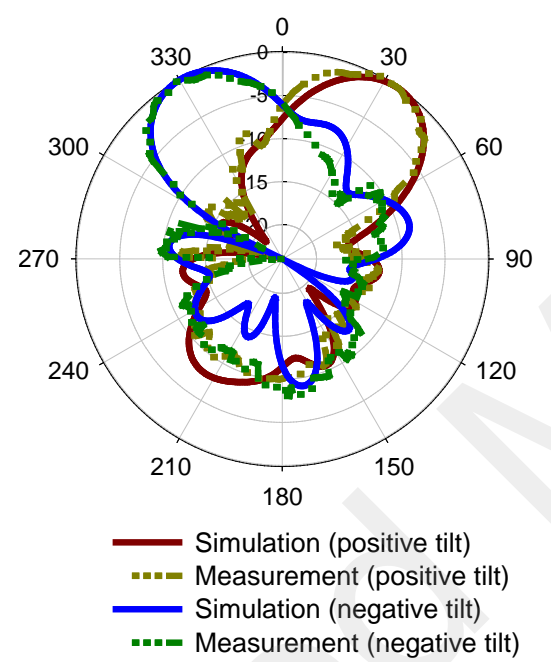

(c)

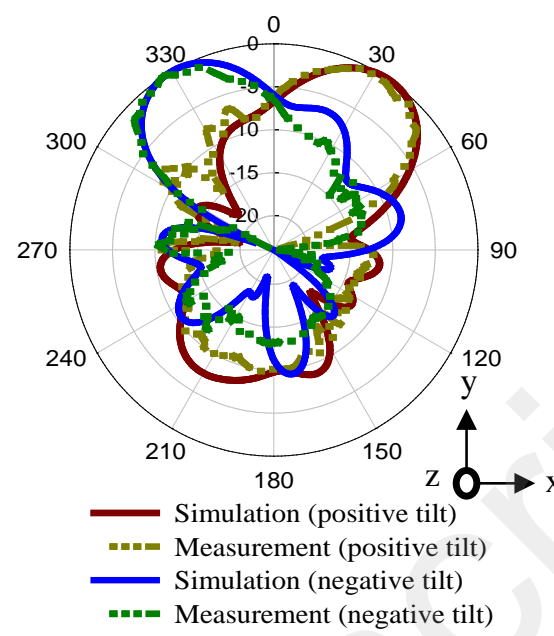

(b)

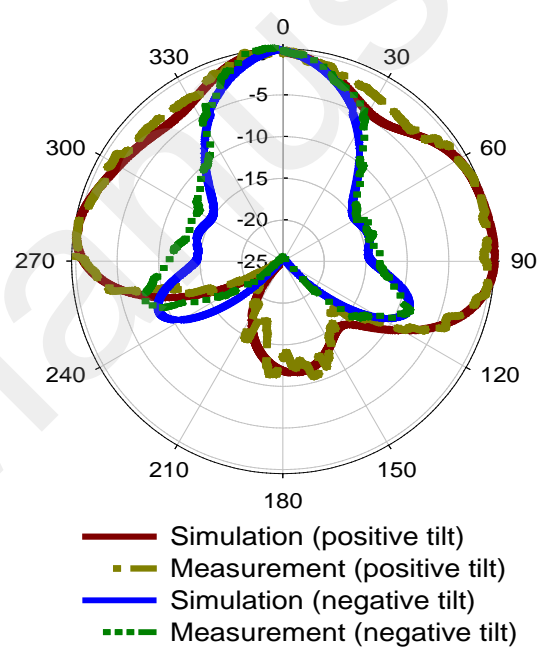

(d)

Figure 11. Normalized simulated and measured results of the radiation patterns in Eplane (positive and negative tilts) at (a) $27.7 \mathrm{GHz}$, (b) $28 \mathrm{GHz}$ and (c) $28.3 \mathrm{GHz}$ and (d) in H-plane at $28 \mathrm{GHz}$.

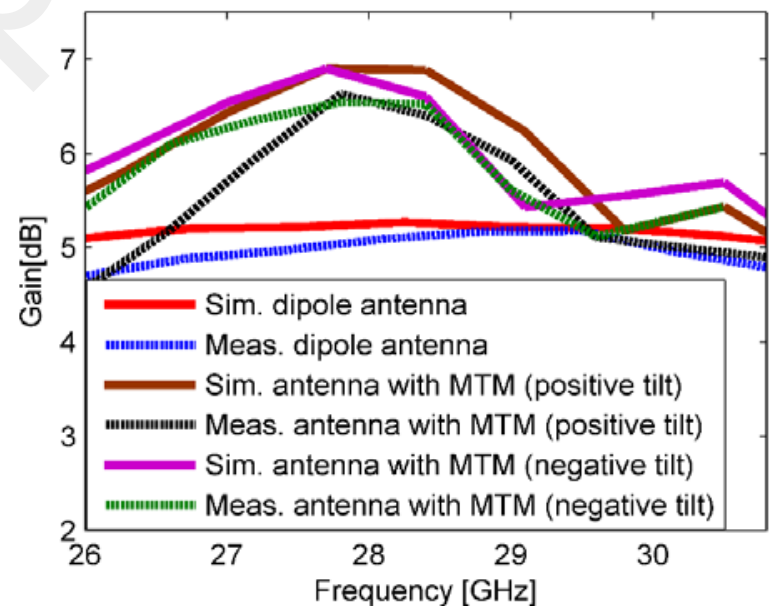

Figure 12. Simulated and measured gain for the dipole antenna, antenna with MTM for positive tilt and antenna with MTM for negative tilt. 